\title{
Intervention, Patronage and Performance
}

\section{A Foreword}

\author{
Clarissa Vierke \\ University of Bayreuth, Bayreuth, Germany \\ clarissa.vierke@uni-bayreuth.de
}

The question of the arts' potential to intervene is a topical one. Art seems to be ubiquitous in forms of recent political protest and interventions morph into artistic practices - so that the boundary between art and political engagement becomes porous. The face of Khalid Said tortured to death by the Egyptian police appeared as graffiti on walls all over Alexandria and Cairo as well as facebook pages in 2010 and 2011 spurring huge mass protests against Mubarak's regime; later a mural received a permanent space in the Goethe Institute of Cairo. ${ }^{1}$ In 2006, the Kenyan artist Sam Hopkins founded Slum TV, enabling the inhabitants of Mathare, one of the largest slums in Nairobi, to film their own news and stories and screen them in the slum. ${ }^{2}$

Considering the arts as a primary political tool meant to liberate the human being from all obstacles on the way to self-fulfillment has a longer tradition in many African contexts. Rather than pitting the essential embeddedness of all art in social contexts in traditional African contexts and arguing against a stereotypically evoked Western art for art's sake, as it has often been done, I would like to put emphasis on the fact that it is a notion deeply entrenched in projects of modernity, which also comes out in the contributions to this special issue.

It was first of all the imagination of the nation state with its promises of unity, prosperity, progress and participation of all, founded on the essential myth of leaving behind a dark period of colonial oppression and exploitation, which inspired so many African artists particularly in the 196os to give form to a bright future yet to be defined. In reflecting upon aspects of the "modern time regime", which essentially breaks with previous notions of present, past

1 Hanan Badr and Carola Richter. "Kollektive Selbstbestimmung in Autokratien? AgendaBuilding im Zusammenspiel von (digitalen) Medien und Aktivisten bei Anti-Folter-Protesten in Ägypten." Medien \& Kommunikation 66.4 (2018): 542-561.

2 See https://www.slumtv.org/ (last visited 21st February 2020). 
and future, Aleida Assmann talks of "the fiction of a new beginning", as one of modernity's pillars, which was, as I want to point out, also frenetically celebrated after independence. ${ }^{3}$ Independence was conceptualized as breaking away from the previous by ways of "creative destruction" (42), another key element of modernity for Assmann. Destructing the shackles of the past by finding new forms of expression, the arts (before any economic fact sheets) played a primary role in imagining African ways into a better future. It is no coincidence that poetry, music and also visual art flourished in many African contexts at that time. Many of the first African state presidents, like, for instance, Léopold Sédar Senghor, Agostino Neto but also Julius Nyerere wrote poetry, since, as Simon Gikandi highlights, there was a close link between politics and writing: "Becoming a writer had been one of the most important sources of legitimacy for the political class in Africa." ${ }^{4}$ The habitus of the politician was that of an intellectually brilliant and rhetorically swift man of the word. The politician was the patron avant la lettre in taking all creative art forms under his auspices. In socialist Tanzania, poets became civil servants of the state meant to imagine a shared narrative in a new language, reexploring African traditions.

Literature was by definition littérature engagée and, to put the argument on its head, all engagement took poetic form. In this sense, African literature did not only draw from Marxist readings and student and Black activist rhetoric in the West, but also inspired the European avantgarde: Jean Paul Sartre, in the first row to proclaim the primary aim of literature as a liberating tool against all kind of alienation, ${ }^{5}$ enthusiastically wrote his essay "Orphée Noir" as a preface for Senghor's anthology of African and Malagassy poetry, attributing a key intellectual role to African poetry for the liberation from centuries of racism and domination. ${ }^{6}$

However, soon, latest in the 1970s and 1980s, the "new beginning" found an early end - even before the massive eruptions of violence in Mozambique, Sierra Leone and Ruanda, where the rhetoric of an open future constantly mov-

3 Aleida Assmann. "Transformations of the Modern Time Regime," in Breaking up Time: Negotiating the Borders between Present, Past and Future, ed. by Chris Lorenz (Göttingen: Vandenhoeck \& Ruprecht, 2013): 42.

4 Simon Gikandi. "Theory, Literature, and Moral Considerations," Research in African Literatures 32.4 (Winter 2001): 1 .

5 More specifically Sartre states: "Chaque livre propose une libération concrète à partir d'une aliénation particulière." In Jean-Paul Sartre. Qu'est-ce que la littérature? (Paris: Gallimard, 1948): 78 .

6 Jean-Paul Sartre. "Orphée Noir," preface to the Anthologie de la nouvelle poésie nègre et malgache de langue française, ed. Léopold Sédar Senghor (Paris: Éditions des PUF, 1948). 
ing towards the better overcoming the dark past became irrevocably buried under heaps of mutilated bodies. While the belief in art as a form of intervention was not given up, literature, for instance, became, primarily, littérature de témoignage, or littérature préemptive as Patrice Nganang would call it, turning towards the past in a new "preemptive style" to prevent the future to repeat its failures-which is markedly different from the notion of a yet to be defined future moving towards the better. ${ }^{7}$

Even earlier, disillusionment started to prevail and the alliance between the political class and the artists crumbled. This time taking the role of opposing and criticizing the strong state ruling with an iron fist, many African authors, musicians and visual artists, continued to take their political role seriously believing in the fundamental liberating and critical nature of the arts. The primary raison d' être of arts became resistance. They criticized the kleptocratic political and economic elite for betraying the hopes, promises and values of independence as much as for becoming the opportunistic handmaidens siding with either the East or the West in a world defined by the dichotomies of the cold war. A suffocating global economy with coercive adjustment plans soon turned development and progress into empty vocabulary. A whole generation of African authors, Ngugi wa Thiong'o and Wole Soyinka being the most emblematic names, believed in the might of the pen, the communitytransforming experience of theatre performances as a way to challenge the ones in power. They were willing to take high risks for their beliefs. Many went to prison and to exile. All intellectualism has been met with the potentate's deep mistrust ever since.

In the 1980s, new "benevolent" patrons made their increasing appearance: Mostly foreign non-governmental organizations, NGOs, came to fight against all kind of proclaimed evils, which the state did or could not care about, like drug abuse, HIV Aids, water scarcity and teenage pregnancies. Besides the education sector, they became the most important commissioners and consumers of artworks and art practices also prescribing a transformative role-in line with their own agenda - to the artworks. Practices of theatre for development, which figures in many contributions in this special issue, and whose main intention was to educate, to create awareness and hence to lead to change in attitude dates mostly back to that time. Again, the NGO's use of arts mirrors the belief in the essentially transformative and therapeutic potential of the arts for the betterment of society. In a context of rapid but uneven social, economic and

7 Patrice Nganang. Manifeste d'une nouvelle littérature africaine. Pour une littérature preemptive. (Paris: Homnisphères, 2007): 284. 
technological change, accelerating since the end of the cold war, offering even more opportunities for a few and bitter experiences of humiliation, disorientation and hopelessness for many, NGO s are part of or compete with religious institutions in conveying values, role models and guidelines for correct behavior.

From the very beginning, NGO s have been met with a suspicion: they have been criticized for imposing a foreign agenda overrunning local ideas and concerns with the power of their foreign currency perpetuating systems of dependency. Also much to the detriment of aesthetic quality, they turn the artist either into a puppet-on-a-string, whose artistic freedom is curtailed or a witty trickster fainting aesthetic ideals, while merely being interested in the money.

Apart from the NGOS, it is the broader businessification of the arts, which has turned patronage into sponsorship. Patronage in many traditional structures of hierarchy of, for instance, royal courts in Africa, grants a stable social role and interdependence to both artist and patron. ${ }^{8}$ Beyond the exchange of money and the market value, both are tied to each other through a web of social obligations, recognition and responsibility. The habitus of both patron and artist is defined along these lines in a reciprocal manner and in terms of specific performative genres, notably the rich panegyric traditions. As Tom Mboya shows in his contribution on live music drawing on Luo praise poetry traditions, the patron's persona depends on the singer, since it is the performer, who calls or sings him socially into being, while it is the patron's prescribed role to compensate the singer. Rather than emphasizing the aspect of power abuse or sheer economic dependence, Mboya stresses the patron's obligation to give. While the payment used to be rather symbolical in nature, in recent decades the monetary value has become increasingly important, often bordering on forms of corruption, which recurred as a topic in the discussions during the workshop.

The all-permeating market economy, which makes money a primary value to define quality and relations, has changed patronage and the possibilities of intervention. New opportunities have emerged. After years of suppression of all kinds of creativity under the Moi regime in Kenya, the 2ooos saw new dynamics in literature, dance, film and visual arts largely funded and supported by other "patrons", including crowd funding, but also various globally acting funding institutions - as elsewhere in the global metropolises, which have become

8 For an overview, see Ruth Finnegan. Oral Literature in Africa (Nairobi and Dar es Salaam: Oxford University Press, 1970): 83-110. 
more and more linked through new technologies and economies. New art spaces opened and projects, like Slum TV described before started in Nairobi; Kwani!, a new literary journal, founded by the late Binyawanga Wainaina showcased new, "subversive", forms of Kenyan and other African literary writing, which gained global recognition, and translated into local spoken word events; the filmmaker Wanuri Kahiu, first shot Pumzi, a 2o-minutes science fiction film, largely produced in South Africa, which envisioned planet earth as a wasteland in the aftermath of its pollution, before winning a prize in Cannes for her feature film Rafiki on a same-sex relationship. ${ }^{9}$ Aligning also with global interventionist concerns of resistance against pollution and homophobia and gaining attention in the West, Kenyan films, like Rafiki, heavily involving sponsorship by mostly European and American funding institutions as well as a markedly different film aesthetics, have caused heated debates about new forms of Western ideological, aesthetic and economic domination.

The expansion of the market for artworks and practices has also effected the mushrooming projects on a smaller scale. In a for me telling way, the notion of "creative industries" has often replaced terms like popular culture or locally produced art practices in many Kenyan discourses. Also in the context of our workshop, we admired the energy and creativity of the students involved. In a context, where the library is largely disjunct and classrooms lack the most basic equipment, they immerse themselves in the production of films dealing with student life, whose quality would have never been possible in this context ten years ago; they create new digital platforms, like a website to share one's own testimonies creating alternative accounts to official news and organize their own events circumventing and challenging official rhetoric and slow bureaucracies. They are smart, which in this context means to be creative, but also business-minded, a quality very much praised in Kenya, wisely exploring the new technological and economic possibilities, primarily offered by new technologies.

This also means that critical intervention increasingly means not to step out of the logic of profit and sale. Resistance has become part of marketing and branding. It is a label put on a product. This does not only hold for staged underground hiphop selling so well locally and globally, but, as the contribution by C.J. Odhiambo shows, big international companies buy (into) a rhetoric of social change. As he critically outlines, one of the big telephone companies in Kenya sponsored a film for development, showcasing social responsibility,

9 Wanuri Kahiu. Pumzi (producer: Simon Hanse, Steven Markovitz) (Cape town: Inspired Minority Pictures, 2009). Wanuri Kahiu. Rafiki (cowriter: Jenna Cato Bass; producer: Steven Markovitz) (Cape Town: Big World Cinema, 2018). 
to enhance its reputation, trading money for commitment. Also in Morocco, it is the telephone company, primarily marketing a street art festival, which was previously a form of protest, as the paper by Farouk El Maarouf and Driss El Maarouf shows. In a similar vein, Marie-Anne Kohl wonders how a critical intervention is possible in the context of a talent show. How can social intervention take place, if the market economy has not silenced but rather engulfed all forms of protest? What if the market becomes the "invisible" patron and intervention as such has turned into a marketable good, sold and offered for money? Is there no Archimedian point anymore to critically observe and attack the market economy from, since it turns into the only political factor and agenda at place?

To dismiss all artistic production "in the age of mechanical reproduction", to echo Benjamin, linked to a growing economization as faking an authentic concern for the better would certainly miss the point, as not only the students' projects presented during the workshop, but also the contribution by Pepetual Mforbe, Annachiara Raia, Yvette Ngum and El-Marouf reminds us of. ${ }^{10}$ It is the existential search for a transcendental, unique and sensuous experience, which speaks from the performative art practices in focus here. It is even the multiplication of possibilities to technically fix and reproduce artforms, so that they can be incessantly played over and over again, which does not kill but rather nurture the need for live performed art. Live music in Eldoret (see the contribution by Mboya) is popular, and even the staged live TV show, in Marie-Anne Kohl's reflections, draws on the "aura", to use another term advocated by Benjamin, of the unique event." It is what Victor Turner outlines as the liminal space in his ritual theory that later influenced performance studies. ${ }^{12}$ The liminal space suspends the everyday, invites for creative border-crossings, explorations of the unknown and suppressed imagination by allowing them to take concrete form. Here lies the transformative potential, since the heightened experience offers alternative vantage points.

\footnotetext{
10 Walter Benjamin. The Work of Art in the Age of Mechanical Reproduction. (London: Penguin, 2008 (1935)).

11 Even if the artistic practice takes the form of a written poem, it is never just a fixed text, but primarily an experience for the reader and the poet, which speaks to the imagination every time anew and easily gives birth to new forms of art, as Annachiara Raia shows in tracing the metamorphosis of poetry through media.

Victor Turner. The Anthropology of Performance (New York NY: PAJ Publications, 1986).
} 


\section{Works Cited}

Assmann, Aleida. "Transformations of the Modern Time Regime," in Breaking up Time: Negotiating the Borders between Present, Past and Future, ed. by Chris Lorenz (Göttingen: Vandenhoeck \& Ruprecht, 2013): 39-56.

Badr, Hanan and Carola Richter. "Kollektive Selbstbestimmung in Autokratien? Agenda-Building im Zusammenspiel von (digitalen) Medien und Aktivisten bei Anti-Folter-Protesten in Ägypten." Medien \& Kommunikation 66.4 (2018): 542-561.

Benjamin, Walter. The Work of Art in the Age of Mechanical Reproduction. (London: Penguin, 2008 (1935)).

Finnegan, Ruth. Oral Literature in Africa (Nairobi and Dar es Salaam: Oxford University Press, 1970).

Gikandi, Simon. "Theory, Literature, and Moral Considerations," Research in African Literatures 32.4 (Winter 2001): 1-18.

Kahiu, Wanuri. Pumzi (producer: Simon Hanse, Steven Markovitz) (Cape town: Inspired Minority Pictures, 2009).

Kahiu, Wanuri. Rafiki (cowriter: Jenna Cato Bass; producer: Steven Markovitz) (Cape Town: Big World Cinema, 2018).

Nganang, Patrice. Manifeste d'une nouvelle littérature africaine. Pour une littérature preemptive. (Paris: Homnisphères, 2007): 284.

Sartre, Jean-Paul. Qu'est-ce que la littérature? (Paris: Gallimard, 1948): 78.

Sartre, Jean-Paul. "Orphée Noir," preface to the Anthologie de la nouvelle poésie nègre et malgache de langue française, ed. Léopold Sédar Senghor (Paris: Éditions des PUF, 1948).

Turner, Victor. The Anthropology of Performance (New York NY: PAJ Publications, 1986). 